\title{
Monosaccharide Recovery from Peat and Peatified Wood by Ultrasonication Pretreatment and Hydrothermal Treatment
}

\author{
Moriyasu Nonaka1, Tsuyoshi Hirajima ${ }^{1}$, Satoshi Kumagai ${ }^{2}$ \\ ${ }^{1}$ Department of Earth Resources Engineering, Faculty of Engineering, Kyushu University, Fukuoka, Japan \\ ${ }^{2}$ Faculty of Agriculture, Department of Applied Biochemistry and Food Science, Saga University, Saga, Japan \\ Email:nonaka@mine.kyushu-u.ac.jp
}

How to cite this paper: Nonaka, M., Hirajima, T. and Kumagai, S. (2017) Monosaccharide Recovery from Peat and Peatified Wood by Ultrasonication Pretreatment and Hydrothermal Treatment. International Journal of Clean Coal and Energy, 6, 31-39. http://dx.doi.org/10.4236/ijcce.2017.62003

Received: February 3, 2017

Accepted: May 19, 2017

Published: May 22, 2017

Copyright (c) 2017 by authors and Scientific Research Publishing Inc. This work is licensed under the Creative Commons Attribution International License (CC BY 4.0).

http://creativecommons.org/licenses/by/4.0/

\begin{abstract}
Peat and peatified wood are significant carbohydrate resources in tropical rainforests. The carbohydrates of cellulose and hemicellulose are important sources of monosaccharides for both vital activities and industrial applications, such as furan production of furfural and hydroxymethyl furfural. Hydrothermal treatment at $200^{\circ} \mathrm{C}$ and ultrasonic irradiation pretreatment were used to recover monosaccharides from the abovementioned resources. The monosaccharide recovery from peat was shown to be higher than that from peatified wood. The conversion to organic acids is considered to proceed rapidly because acids are always detected with monosaccharides. This conversion is outstripped by the organic acid-to-gas reaction for treatment times longer than $20 \mathrm{~min}$. The monosaccharide recovery from peatified wood was improved by the ultrasonication pretreatment. It is considered that ultrasonic irradiation broke down lignin blockages, enabling water molecules to access the carbohydrates more easily in the subsequent hydrothermal treatment.
\end{abstract}

\section{Keywords}

Peat, Peatified Wood, Hydrothermal Treatment, Ultrasonication, Monosaccharide

\section{Introduction}

Peat is present in vast swamps in tropical rainforests and is presumed an extensive low-quality carbonaceous resource with the estimated occupation area of 16.5 - 27 million hectares in Indonesia alone [1]. Peat has a high water content of $80 \%-90 \%$ in nature because the majority of biomass oxygen-containing func- 
tional groups remain after peatification. For such a highly hydrophilic material, upgrading is necessary to convert it to high-quality fuel. Non-evaporative upgrading techniques, including hydrothermal treatment, show particularly high energetic effectiveness because the reactions occur in the liquid phase, making drying pretreatment unnecessary. Mursito et al. demonstrated the potential of hydrothermal treatment as a technique for recovering valuable chemicals, combustible gases, and high-calorie solid fuels from peat [2]. They also showed the existence of the biomass components of cellulose and hemicellulose in raw peat through a nuclear magnetic resonance (NMR) spectroscopic study [3]. These carbohydrates have attracted attention as sources of sugars.

Hydrothermal treatment of cellulose and hemicellulose in lignocellulosic biomassis widely used to produce sugar. Bobleter et al. have led research showing the importance of hydrolysis reactions in decomposing cellulose in hot compressed water, using cellobiose as a model compound of cellulose [4] [5]. Sakaki et al. observed the decomposition behaviors of cellulose using a flow-type hydrothermal reactor. The main components in the liquid phase discharged from the cell were saccharides, heavier component of which became polymerized in deposition after cooling [6]. Kumagai et al. demonstrated the extraction of various sugars from Moso-bamboo by hydrothermal treatment at temperatures between $180^{\circ} \mathrm{C}$ and $300^{\circ} \mathrm{C}$. The decrease in hemicellulose in the solid residue and the increase in xylose extraction yields showed a good correlation. Furthermore, glucose can be converted to ethanol by biological method, and both glucose and xylose are precursors of furans obtained by dehydration [7]. Furfural, a typical furan, has many applications in the fields of oil refinery, plastics, pharmaceutics, agrochemical industries, and non-petroleum-derived saccharidederived chemicals [8] [9]. Thus, the recovery of sugars from inedible substances has further application possibilities, hydrothermal treatment, lacking the addition of toxic, corrosive and difficult-to-use acids is a particularly promising recovery method.

It is useful to target peat and peatified wood for producing these value-added chemicals from the perspective of the cascade utilization of low-grade carbonaceous materials. In this study, our efforts focused on the recovery of monosaccharides from peat and peatified wood by hydrothermal treatment and the facilitation of monosaccharide recovery by ultrasonic irradiation pretreatment.

\section{Experimental}

The low-grade carbonaceous materials used in this study were Indonesian peat and peatified wood, which is distinguished from peat by its wood-like visual characteristics. They were pulverized to less than $0.5 \mathrm{~mm}$ in size for homogenization using a cutter mill with a head rotating speed of $6000 \mathrm{rpm}$ (Model no: MF 10 and 10.1, IKA). The air-dried materials were used for biomass component analysis based on a report by the National Renewable Energy Laboratory (NREL) [10]. Ultrasonic irradiation pretreatments were conducted on a wellslurrified sample at frequencies of $28 \mathrm{kHz}, 200 \mathrm{kHz}$, or $600 \mathrm{kHz}$. The agitation of 
$200 \mathrm{rpm}$ was used for both the ultrasonication and the slurrification. The ultrasonicated sample was dried, mixed well and homogenized again before hydrothermal treatment. Hydrothermal treatment was conducted using a batch-type reactor with dimensions of $14.8 \mathrm{~mm}$ in inner diameter and $80 \mathrm{~mm}$ in length, and a $6.35 \mathrm{~mm}$ stainless steel pipe arm with a K-thermocouple inside and a valve at the opposite side (Figure 1). The vessel was filled with $1 \mathrm{~g}$ of peat or $0.4 \mathrm{~g}$ of peatified wood, measured in the air-dried state, and $8 \mathrm{~g}$ of water. The inner void space was purged with nitrogen at 1.0 MPa after three-repeated cycles of charging and discharging through the valve. The vessel was shaken vigorously and held at $200^{\circ} \mathrm{C}$ for $5 \mathrm{~min}$ in a fused salt bath $\left(\mathrm{KNO}_{3}: \mathrm{NaNO}_{2}: \mathrm{NaNO}_{3}=53: 40: 7\right)$, before transfer to a water bath to cool and stop the hydrothermal reaction. The hydrothermally treated slurry was recovered after exhausting the gas through the valve. The slurry was filtered using a $0.45-\mu \mathrm{m}$ pore-sized membrane filter into solid and liquid phases. Monosaccharides and organic acids in the liquid phase were quantified by high-performance liquid chromatography (HPLC, Detectors: RI-2031Plus, Eluent: $2 \mathrm{mM} \mathrm{HClO}_{4}(0.7 \mathrm{~mL} / \mathrm{min})$, Column: Shodex KC-811).

\section{Results and Discussion}

The contents of the carbohydrates measured by the NREL method are summarized in Table 1. Peatified wood, which is less peatified and maintains a biomass

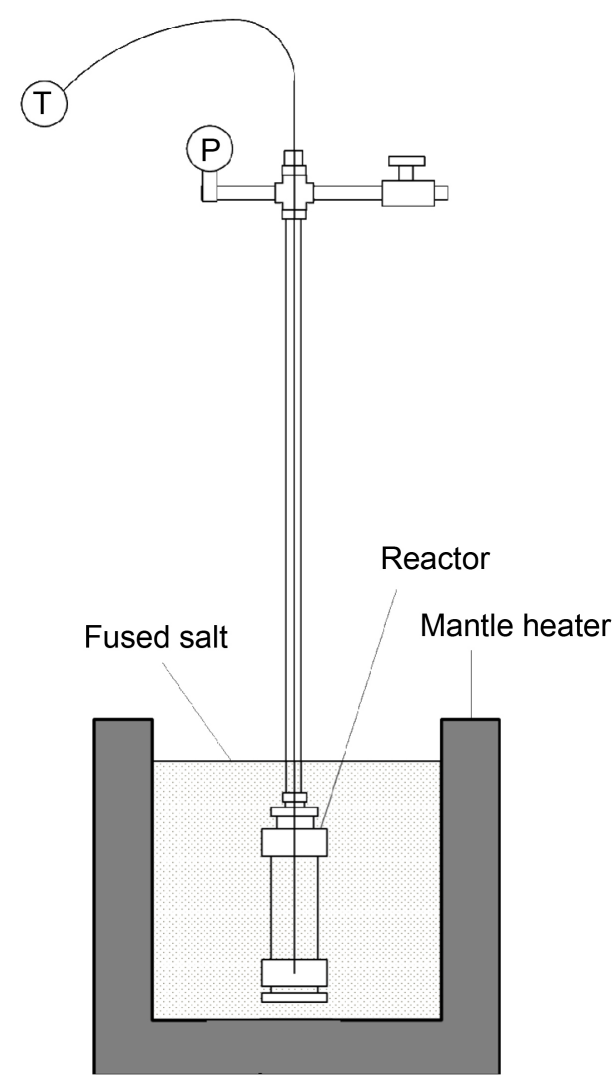

Figure 1. Schematic of the apparatus. "T" and "P" denote thermometric and pressure sensors, respectively. 
Table 1. Constituent contents based on the compositional analysis of biomass.

\begin{tabular}{ccc}
\hline & Peat & Peatified wood \\
\hline Cellulose & 2.4 & 23.0 \\
Hemicellulose & 0.6 & 2.7 \\
Acid insolubles & 73.8 & 55.8 \\
Wax & 8.6 & 2.7 \\
Ash & 1.4 & 0.6 \\
\hline
\end{tabular}

shape, has a higher carbohydrate content than peat does. The higher wax content of peat is considered to arises from depolymerization during peatification; the slightly higher ash content may be attributed to the transfer of minerals from the geological surroundings.

The recoveries for the monosaccharides of glucose and xylose and organic acids by the 5 -min hydrothermal treatment at $200^{\circ} \mathrm{C}$ for the two samples are summarized in Figure 2. Glucose, a hydrolysis product of cellulose, is extracted in the liquid phase. Xylose is mainly a hydrolysis product from hemicellulose. These monosaccharides in the liquid phase decompose further into organic acids. These successive hydrothermal reactions seem to occur in a short time, because organic acids are always detected with monosaccharides. For peat (denoted as Peat 200-5), 15\% of cellulose is extracted as glucose while approximately $40 \%$ of the total (cellulose and hemicellulose) is recovered as monosaccharides, and approximately $15 \%$ of the total carbohydrate content is further transformed to organic acids. These values are all higher than those for peatified wood; the recoveries of glucose, monosaccharides and organic acids for peatified wood (denoted as Peatified wood $200-5$ ) are $0.8 \%, 7.7 \%$ and $0.9 \%$, respectively. This means that $45 \%$ of carbohydrates in the peat survived the hydrothermal treatment and remained in the residue, whereas the remaining carbohydrates over whelm the reacted ones in the peatified wood. In past studies, researchers have reported on the solubilization trends of chemical cellulose [11] and biomass cellulose [12] in hydrothermal condition. Both types of cellulose showed difficulty in decomposition below $230^{\circ} \mathrm{C}$. One possible reason for the decomposition difficulty below $230^{\circ} \mathrm{C}$ is the crystallinity of cellulose; cellulose molecules form strong hydrogen bonds with each other that water molecules cannot attack easily. With lignocellulosic biomass, another factor impeding decomposition is lignin blockages; hot compressed water molecules must destroy these blockages to access the cellulose [13]. The higher decomposability of the carbohydrates in the peat is probably due to the loosening of lignin blockages during peatification and therefore the improved accessibility of hot compressed water molecules to the carbohydrates. Peatified wood is less peatified peat; therefore, the decomposition may be restricted by the firmer lignin structure and higher cellulose crystallinity. Figure 3 shows the variation in the recoveries of monosaccharides and organic acids in the liquid phase obtained by the hydrothermal treatment of peat as a function of the reaction time. The monosaccharide (glucose and xylose) recovery from the carbohydrates (cellulose and hemicellulose) is maximized at 


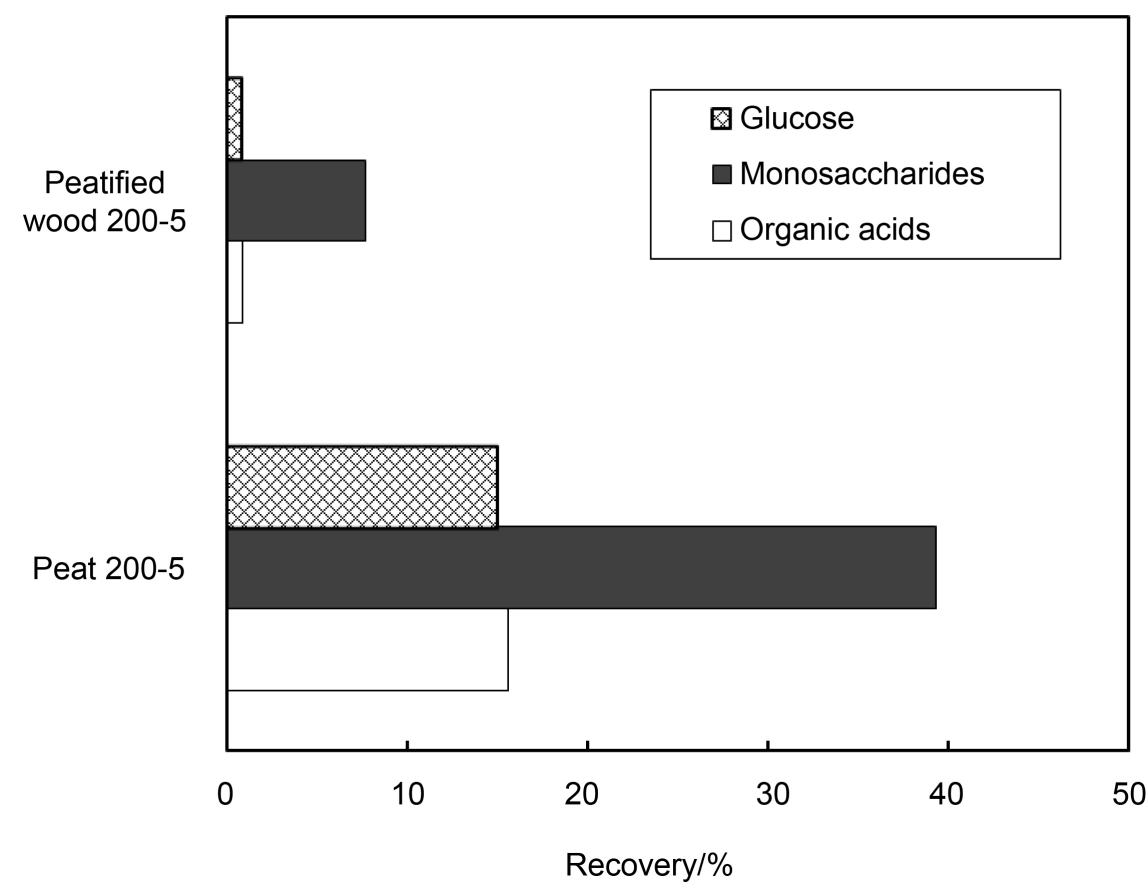

Figure 2. Recoveries of glucose, monosaccharides and organic acids from peat and peatified wood by hydrothermal treatment.

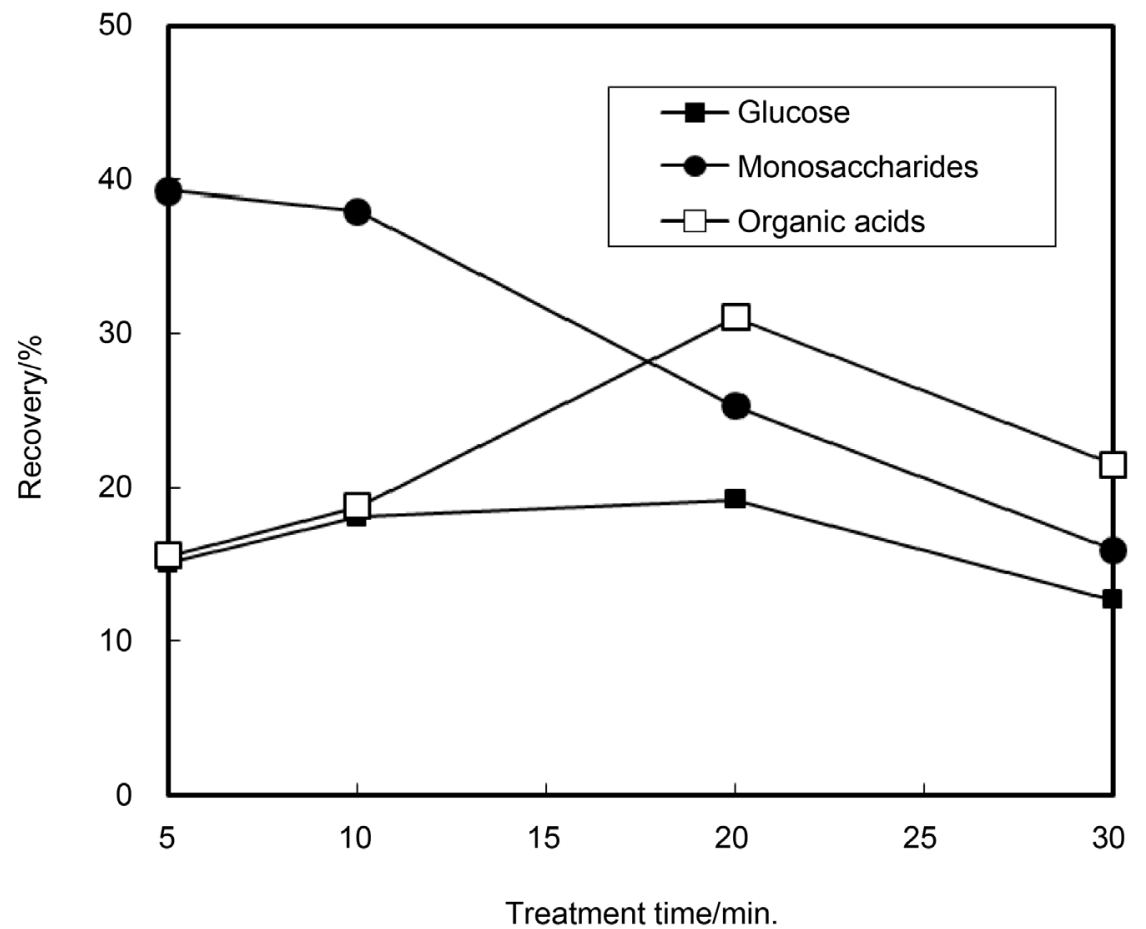

Figure 3. Variations over time in the recoveries of glucose, monosaccharides and organic acids from peat by hydrothermal treatment.

approximately $40 \%$ after $5 \mathrm{~min}$, showing a gradual decrease and the minimum recovery of approximately $16 \%$ at $30 \mathrm{~min}$. Meanwhile, glucose requires more time for extraction, as its recovery peaks at approximately 19\% after $20 \mathrm{~min}$. 
This indicates that decomposition of hemicellulose is easier than that of cellulose in hot compressed water. This agrees with the findings of Kumagai et al., where easier hemicellulose decomposition was attributed to the difference in the reaction temperature for effective decomposition: $180^{\circ} \mathrm{C}$ for hemicellulose and $240^{\circ} \mathrm{C}$ for cellulose [7]. Reaction times longer than 20 min show decreased organic acids recovery. It is considered that the hydrothermal decomposition reaction has progressed further and the organic acids-to-gas reaction occurs more quickly than the reaction producing organic acids from sugarsaftermore than 20 minutes of hydrothermal treatment.

Endeavors to improve the recovery of monosaccharides from peatified wood, which showed less decomposability in hot compressed water than peat, were performed by adopting an ultrasonication pretreatment before hydrothermal treatment. Figure 4 shows the effect of ultrasonic pretreatment time on the recoveries of glucose, monosaccharides, and organic acids by the subsequent hydrothermal treatment. Ultrasonication of $45 \mathrm{~min}$ shows a peak for these three recoveries; both the value and the rate of increasing in the monosaccharide recovery are high. This indicates that ultrasonic irradiation comprehensively affects the carbohydrates, enhancing the hydrothermal reactions, such as the conversion of cellulose to glucose, cellulose and hemicellulose to xylose, and monosaccharides to organic acids. Yunus et al. conducted ultrasonication pretreatment of oil palm empty fruit bunches (OPEFBs) before acid hydrolysis. They confirmed that silica bodies were removed from the surface of the fibers; craters with holes at the bottoms appeared after silica removal. Such holes, when exposed to the aqueous solution, allowed water molecules to penetrate the OPEFB

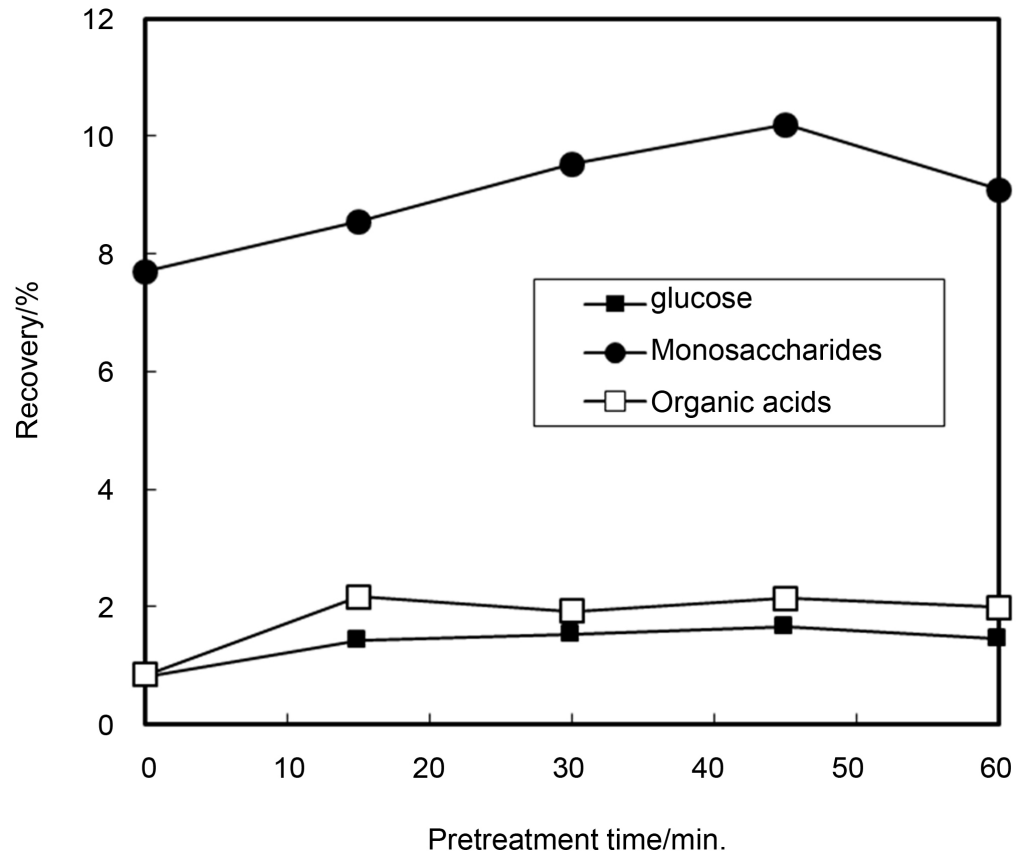

Figure 4. Effect of ultrasonic pretreatment time on the recoveries of glucose, monosaccharides, and organic acids from peatified wood by the subsequent hydrothermal treatment. 
fibers and the hydrolyzed hemicellulose, thereby increasing in the recovery of xylose [14]. From scanning electron microscopy (SEM) observations, our raw sample had no silica bodies on its surface. One possible reason for the absence of silica bodies is the differences in the preparation methods of the raw samples. Our preparation method was pulverization using a cutter mill with a head rotating at $6000 \mathrm{rpm}$, which produced powder samples smaller than $0.5 \mathrm{~mm}$ in diameter; on the other hand, Yunus et al. utilized shredding with a chopping action that gave less impact and produced coarser particles. Otherwise, our sample may have simply lost the silica bodies during the long peatification era. Another possible reason is based on the non-crystalline structure. Hemicellulose, which originally lacks the firm crystal structure of cellulose, is likely to be loosened by ultrasonic irradiation, which enables water molecules to penetrate and decompose the loosened hemicellulose. In this way, the decomposition of the amorphous part of cellulose by ultrasonic irradiation may have contributed to the slight increase in glucose recovery. As shown in Figure 5, the ultrasound irradiation exhibits the most effective reactivity at $200 \mathrm{kHz}$, regarding the recovery of not only monosaccharides from carbohydrates, but also glucose from cellulose. Tiehm et al. investigated the disintegration of sludge under ultrasonic irradiation at frequencies between 41 and $3217 \mathrm{kHz}$. They clarified that the increased cavitation bubble size, inversely proportional to the resonance frequency, effectively enhanced the degree of sludge disintegration. This phenomenon could be produced by two characteristics of cavitation: powerful hydromechanical shear forces and sonochemical reactions [15]. In other words, larger cavitation bubbles, produced at the smaller resonance frequencies, collapse more of the microbial cells in the sludge by their stronger mechanical forces. On the other hand,

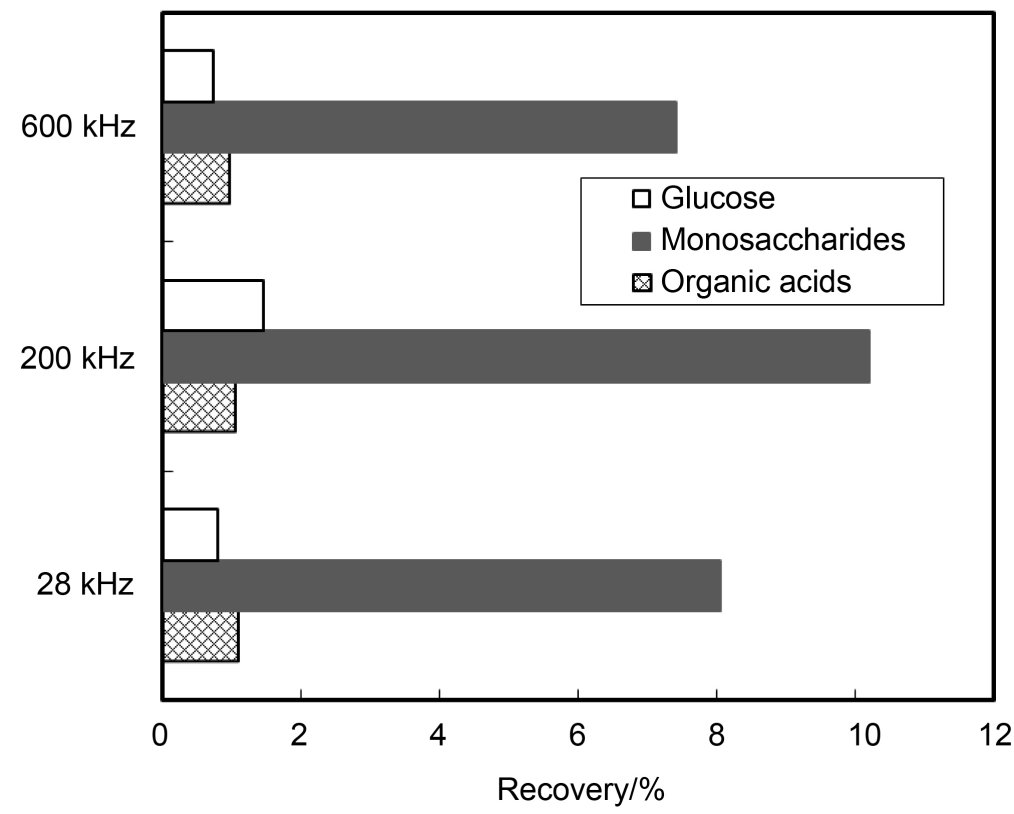

Figure 5. Effect of ultrasonication frequency on the recoveries of glucose, monosaccharides, and organic acids from peatified wood by the subsequent hydrothermal treatment. 
Toma reported qualitatively that the frequency of $500 \mathrm{kHz}$ softened the middle lamella of vegetal tissues, whereas that of $20 \mathrm{kHz}$ had a strong mechanical effect [16]. The effects of ultrasonication were considered to contribute to disintegrating cellular substances, exposing the collapsed cells to a solvent, and increasing the extraction rate. In our system using peatified wood, ultrasonication at 200 $\mathrm{kHz}$ showed the strongest effect on the disintegration of peatified wood.

\section{Conclusion}

Attempts to recover monosaccharides from peat and peatified wood, which is less peatified, by hydrothermal treatment at $200^{\circ} \mathrm{C}$, and to facilitate the recovery by ultrasonic irradiation pretreatments, were conducted. Hydrothermal treatment of the peat for $5 \mathrm{~min}$ showed higher recoveries than those of peatified wood, probably because of the loosening of lignin blockages during peatification. The recoveries of glucose from cellulose, monosaccharides from carbohydrates, and organic acids from carbohydrates were approximately $15 \%, 40 \%$ and $15 \%$, respectively, after 5-min hydrothermal treatment. Increasing treatment times below 20 min showed increases in glucose and decreases in xylose recoveries, because of the greater decomposability of hemicellulose compared to cellulose. In the same range of treatment times, glucose and xylose sugars were partly converted to organic acids. The sugar-to-acids conversion reaction was probably outstripped by the conversion reaction of organic acids-to-gas for treatment times greater than 20 minutes. The greatest improvements in the recoveries for peatified wood were achieved by performing ultrasonication pretreatment for 45 minutes of irradiation at the frequency of $200 \mathrm{kHz}$.

\section{References}

[1] Sorensen, K.W. (1993) Indonesian Peat Swamp Forests and Their Role as a Carbon Sink. Chemosphere, 6, 1065-1082.

[2] Mursito, A.T., Hirajima, T., Sasaki, K. and Kumagai, S. (2010) The Effect of Hydrothermal Dewaternig of Pontianak Tropical Peat on Organics in Wastewater and Gaseous Products. Fuel, 89, 3934-3942.

[3] Mursito, A.T., Hirajima, T. and Sasaki, K. (2010) Upgrading and Dewartering of Raw Tropical Peat by Hydrothermal Treatment. Fuel, 89, 635-641.

[4] Bobleter, O. and Bonn, G. (1983) The Hydrothermolysis of Cellobiose and Its Reaction-Product D-Glucose. Carbohydrate Research, 124, 185-193.

[5] Bobleter, O. (1994) Hydrothermal Degradation of Polymers Derived from Plants. Progress in Polymer Science, 19, 797-841.

[6] Sakaki, T., Shibata, M., Sumi, T. and Yasuda, S. (2002) Saccharification of Cellulose Using a Hot-Compressed Water-Flow Reactor. Industrial \& Engineering Chemistry Research, 41, 661-665. https://doi.org/10.1021/ie010614s

[7] Kumagai, S., Hirajima, T., Nonaka, M. and Hayashi, N. (2012) Hydrothermal Carbonization Behavior of Moso-Bamboo (Phyllostachys heterocycla) in Hot-Compressed Water. Wood Carbonization Research, 8, 53-60.

[8] Weil, J.R., Dien, B., Bothast, R., Hendrickson, R., Mosier, N.S. and Ladisch, M.C. (2002) Removal of Fermentation Inhibitors Formed during Pretreatment of Biomass by Polymeric Adsorbents. Industrial \& Engineering Chemistry Research, 41, 


\section{2-6138. https://doi.org/10.1021/ie0201056}

[9] Mamman, A.S., Lee, J.M., Kim, Y.C., Hwang, I.T., Park, N.J., Hwang, Y.K., Chang, J.S. and Hwang, J.S. (2008) Furfural: Hemicellulose/Xylose-Derived Biochemical. Biofuels, Bioproducts \& Biorefining, 2, 438-454. https://doi.org/10.1002/bbb.95

[10] National Renewable Energy Laboratory (2008) Laboratory Analytical Procedure, Technical Report, NREL/TP-510-42618-42623, 42625, 42627.

[11] Gao, Y., Wang, X.H., Yang, H.P. and Chen, H.P. (2012) Characterization of Products from Hydrothermal Treatments of Cellulose. Energy, 42, 457-465.

[12] Kumagai, S., Hayashi, N., Sasaki, T., Nakada, M. and Shibata, M. (2004) Fractionation and Saccharification of Cellulose and Hemicellulose in Rice Hull by HotCompressed-Water Treatment with Two-Step Heating. Journal of the Japan Institute of Energy, 83, 776-781. https://doi.org/10.3775/jie.83.776

[13] Mosier, N., Wyman, C., Dale, B., Elander, R., Lee, Y.Y., Holtzapple, M. and Ladisch, M. (2005) Features of Promising Technologies for Pretreatment of Lignocellulosic Biomass. Bioresource Technology, 96, 673-686.

[14] Yunus, R., Salleh, S.F., Abdullah, N. and Biak, D.R.A. (2010) Effect of Ultrasonic Pre-Treatment on Low Temperature Acid Hydrolysis of Oil Palm Empty Fruit Bunch. Bioresource Technology, 101, 9792-9796.

[15] Tiehm, A., Nickel, K., Zellhorn, M. and Neis, U. (2001) Ultrasonic Waste Activated Sludge Disintegration for Improving Anaerobic Stabilization. Water Research, 35, 2003-2009.

[16] Toma, M., Vinatoru, M., Paniwnyk, L. and Mason, T.J. (2001) Investigation of the Effects of Ultrasound on Vegetal Tissues during Solvent Extraction. Ultrasonics Sonochemistry, 8, 137-142.

\section{Submit or recommend next manuscript to SCIRP and we will provide best} service for you:

Accepting pre-submission inquiries through Email, Facebook, LinkedIn, Twitter, etc. A wide selection of journals (inclusive of 9 subjects, more than 200 journals)

Providing 24-hour high-quality service

User-friendly online submission system

Fair and swift peer-review system

Efficient typesetting and proofreading procedure

Display of the result of downloads and visits, as well as the number of cited articles

Maximum dissemination of your research work

Submit your manuscript at: http://papersubmission.scirp.org/

Or contact ijcce@scirp.org 